\title{
EXTERNAL AND DOMESTIC CHALLENGES AND PROSPECTS FOR TURKEY AS A REGIONAL POWER AND THE ROLE OF THE EUROPEAN UNION
}

\author{
Selcen Öner \\ Bahçeşehir University-İstanbul, Turkey
}

\begin{abstract}
Turkey, which has a democratic and secular political system with a predominantly Muslim population and an EU membership prospect, had an increasing influence in its region which increased its soft power. However, after the start of Arab uprisings, uncertainty in the Middle East and stall of the negotiations with the EU challenged Turkey's soft power. This article discusses challenges and prospects facing Turkey's regional power, especially since 2011. It firstly analyses the role of soft power in Turkish foreign policy and evaluates the series of soft power instruments. Secondly, it discusses the external factors challenging Turkey's regional power, particularly the role of Arab uprisings, particularly Syrian crisis and domestic challenges that negatively influence Turkey's regional power, particularly stagnation in the reform process, polarisation of the society, freedom of media and the rise of terrorism. Lastly the role of EU in Turkey's soft power in spite of its decreasing transformative power over Turkey in recent years will be evaluated.
\end{abstract}

Keywords: Turkey; Regional Power; Soft Power; Syrian Crisis; European Union

\section{Introduction}

Joseph Nye (2008) defined power as 'the ability to affect others to obtain the outcomes you want', with three main ways to affect the other's behaviour: 'Threats of coercion, inducements and payments and attraction that makes others what you want'. The term 'soft power' ${ }^{\text {' }}$ was first used by Nye $(2004$, p. 5), who defined it as 'the ability to shape the preferences of others'. If others follow the lead of the power holder due to the power of attraction, we can speak of soft power. Soft power resources include cultural attraction, ideology and international institutions.

1) This concept was introduced by Joseph Nye in his 1989 book which is called "Bound to Lead". 
Legitimacy and credibility are necessary conditions for the existence of soft power, because 'if a state can make its power seem legitimate in the eyes of others, it will encounter less resistance to its wishes' (Nye, 1990, p. 167). While 'hard power' assumes an emphasis on the agent, 'soft power' emphasises the significance of others' perceptions of the agent (Oğuzlu, 2007, p. 82-84).

Nye (2008, p. 106) argues that part of the USA's soft power comes from the openness of its society and its free press, Congress and courts that can criticize and correct government policies. While soft power was firstly introduced to counter the belief in the US' global decline, it has been also used in relation to the foreign policy discourse of mid-range regional powers like Turkey'. In particular, many Turkish foreign policy scholars claim that Turkey's soft power, particularly in the Middle East, has increased in the first decade of the 21st century ${ }^{2}$ (Demiryol, 2014, p. 7).

If a country has soft power, other countries want to follow it as an example, admiring its values, level of prosperity and openness. In international politics, soft power usually depends on a country's values, the example set by its domestic policies, and its relations with others. Public diplomacy is an instrument that governments use to communicate with and attract the publics of other countries. However, it should be emphasized that 'if the content of a country's culture, values and policies are not attractive, public diplomacy that broadcasts them can not produce soft power' (Nye, 2008, p. 94-95). Nye (2008, p. 101-108) also argues that 'good public diplomacy has to go beyond propaganda'. While providing information and selling a positive image is part of public diplomacy, the latter also involves building the longterm relations that create an 'enabling environment for government policies'. In this way, public diplomacy can be used as an instrument to promote a country's soft power.

In 2003, Nye (2009, p. 160-161) introduced the concept of 'smart power' in order to counter the misunderstanding that only soft power can produce effective foreign policy. While Nye defines hard power as 'the use of coercion and payment', he defines 'soft power' as 'the ability to obtain preferred outcomes through attraction'. The major elements of soft power include a country's culture and values, so long as they

2) For further detail see Tarik Oguzlu, "Soft Power in Turkish Foreign Policy", Australian Journal of International Affairs, Vol. 61, No. 1, 2007; Meliha Benli Altunışık, "The Possibilities and Limits of Turkey's Soft Power in the Middle East", Turkish Studies, Vol. 10, No. 2, 2008. 
are attractive, and its policies, if they are practised in a consistent way and perceived as legitimate and inclusive. The instruments of soft power include public diplomacy, development assistance and exchange programmes. However, he also argues that there is a necessity for smart strategies that combine the instruments of both hard and soft power. He proposes that these can be combined as 'smart-power strategies' that can be used together, although this requires 'contextual intelligence', based on realistically understanding both the strengths and limits of the country's power. Nye (2008, p.94) argues that public diplomacy is also an instrument of 'smart power', but 'smart public diplomacy requires an understanding of the roles of credibility, self-criticism and civil society in generating soft power'.

During the Cold War era and in the 1990s, Turkey was considered mostly as a 'hard power'. In the first decade of the $21^{\text {st }}$ century, several internal and external developments have positively contributed to Turkey's soft power. As a secular, democratic state with a predominantly Muslim population, an official candidate of the EU since 1999, Turkey developed a growing regional influence since September 11. Especially, after the Arab Spring, there were discussions on whether Turkey's political and socioeconomic transformation can provide an example or an 'inspiration' for opposition forces in the Arab world (Benli Altunışı, 2011, p. 1).

While in its first (2002-2007) term of office, the Justice and Development Party (JDP) government gave priority to the EU accession process, in its second term (2007-2011), it developed a multi-dimensional approach to Turkish foreign policy. ${ }^{3}$ In particular, Turkey tried to contribute to regional peace through constructive engagement and mediation efforts in its neighbouring regions. Turkey's 'zero problems policy' also contributed to its soft power, including a liberal visa policy with its neighbours and increasing economic, political and cultural communication and cooperation. Turkey was constructed in the first decade of the $21^{\text {st }}$ century as a 'central country'. Turkey has started to use public diplomacy to communicate with various countries, with Turkish language courses and cultural centres being established in different parts of the world. There has also been a rise in interest in Turkish language

3) For further detail see Selcen Öner, "Europeanization of Turkish Foreign Policy and Increasing Multidimensional Approach", EurOrient, "Turquie: La Nouvelle Politique Exterieure Turque Entre Le Mythe 'Europeen' et la Nostalgie 'Ottomane"' (The New Turkish Foreign Policy between the European Myth and the Ottoman Nostalgia"), No:35-36, 2011, p.217-236. 
and culture, especially with the rising popularity of Turkish soap operas in the Middle East and the Balkans.

During the third term of the JDP government (2011-2015) the Arab Spring was the main challenge for Turkey's soft power. The strategy of promoting and projecting Turkish culture externally, is insufficient as long as hard power and uncertainty dominate in the Middle East (Benli Altunışık, 2011, p. 2-3). Turkey's soft power in the Middle East has also been challenged by other countries that perceive this region as crucial for their own geostrategic interests (Beng, 2008, p. 38). As Oğuzlu (2007, p. 95) argues, if threats and challenges to Turkey's own security continue to increase, it will lead to an increase in Turkish tendencies to revert to acting as a hard power. For example, growing tensions between Turkey and Syria, stalled negotiations with the EU, and the loss of momentum in Turkey's domestic reform process, particularly regarding freedom of speech and media, have negatively influenced Turkey's soft power. Turkey's ability to exert soft power in the Middle East is also dependent on 'undertaking necessary reforms at home to make Turkey's development attractive and persuasive to others' (Beng, 2008, p. 22). For Turkey's regional soft power to recover, will require its domestic reform process to regain its earlier momentum and improvements in its democratic credibility.

This article discusses the challenges and prospects facing Turkey's soft power, especially since 2011, during the JDP government's third term and the fourth term since 2015. It firstly analyses the role of soft power in Turkish foreign policy and evaluates the series of soft power instruments. Secondly, it discusses the stagnation in the reform process and the domestic challenges facing Turkey's soft power, particularly deficiencies in freedom of speech and freedom of press, and lastly the role of external factors which include the role of Arab uprisings, particularly Syrian crisis and the role of the EU in Turkey's soft power.

\section{The Development of Instruments for Turkey's Soft Power}

Turkey used various foreign policy tools in dealing with neighbouring regions, including public diplomacy, and developmental assistance. The primary institutional instruments of Turkey's soft power are TIKA (Turkish International Cooperation and Development Agency), which provides developmental assistance to many countries, and the Institute of Public Diplomacy, which plays a crucial role in 'promoting Turkey's image 
abroad' (Demiryol, 2014, p. 9). In addition, Yunus Emre Turkish cultural centres have been established in different parts of the world, especially in neighbouring regions, to promote Turkish language and culture abroad.

In 2010 the Office of Public Diplomacy was established within the Turkish Prime Ministry. Turkey's public diplomacy has two main pillars: 'from state to society' and 'from society to society'. The first focuses on explaining Turkish government policies and activities to an international public. The second uses civil instruments, such as CSOs, research institutes, the press and universities (Kamu Diplomasisi, 2010) for communication activities. The goal of this public diplomacy is to increase Turkey's visibility in international public opinion. Activities involve science and technology, economy, tourism, culture, arts, foreign aid and media, which help to inform world public opinion about Turkey. By coordinating these activities, the Office of Public Diplomacy tries to support Turkey's strategic efforts to communicate and promote itself effectively internationally (Vizyon ve Misyon, 2010). İbrahim Kalın (2011, p. 5-10), former head of the Office of Public Diplomacy, defines public diplomacy as a platform for the implementation of soft power, arguing that its influence extends from the Balkans to the Middle East and Central Asia.

The activities of Turkish public diplomacy include conference series of 'wise men', journalist group programs, country programs, meetings with representatives of the foreign press, promotional activities, public diplomacy panels, foreign policy workshops, Europe meetings and the İstanbul Global Forum, held for the first time in October 2012 with the participation of politicians, academics, writers, journalists and artists. The conference series of 'wise men' aims to bring foreign politicians, intellectuals, journalists and specialists to Turkey, such as Seyyid Hüseyin Nasr and George Friedman, while the journalist groups program aims to invite journalists from the foreign press to Turkey so that they can attend meetings with Turkish journalists, media representatives and research institutions. The goal of meeting representatives of the foreign press in Turkey is to give them a chance to come together regularly with Turkish decision-makers, who can inform them about various policies and recent developments in Turkey. The country programmes involve meetings held abroad that aim to bring together foreign researchers and specialists on Turkey with their Turkish colleagues. Public diplomacy panels that include specialists and high-level bureaucrats are organized each month in a different Turkish city with the cooperation of the local university. Foreign policy workshops are also held in different cities and 
include academics and foreign policy makers. Europe meetings involve academics and thinkers specialised on European identity and culture to conduct discussions about the future of Europe (Faaliyetler, 2010).

By abolishing visa requirements for citizens from neighbouring countries like Syria, Egypt, Lebanon and Iran, Turkey strengthened its soft power by increasing interactions with these countries. For example, it allowed Turkish Civil Society Organisations (CSOs) and business organisations to become more active in neighbouring regions. As a state institution operating under the Turkish Prime Ministry since 1992, TIKA is regarded as a key foreign policy instrument for increasing regional cooperation in the Middle East, Caucasus, Central Asia, Balkans and Africa (Kaya and Tecmen, 2011, p. 13). TIKA deals with a range of projects in education, health, restoration, agricultural development, tourism and industry, with Programme Offices being established in 12 other countries in 2002, before expanding to 33 offices in 30 countries in 2012. Whereas Turkey's development funds amounted to 85 million US dollars in 2002, by 2011 it reached 1.273 billion US dollars (TIKA, 2013). According to the 2013 Global Humanitarian Assistance Report, Turkey was the fourth largest humanitarian aid donor in 2012 after the USA, the EU and the UK (cited in Aydın-Düzgit and Keyman, 2014). This overseas development assistance programme is in accordance with Turkish foreign policy's rhetoric of a 'historical responsibility' towards neighbouring regions (Elman, 2013, p.3). For example, a scholarship programme was incorporated in TIKA that enables an increasing number of overseas students from Turkey's neighbourhood (Kirişçi, 2011, p. 42).

Turkey's cultural diplomacy is carried out within the scope of Turkish foreign policy under the jurisdiction of the Ministry of Foreign Affairs, although the Ministry of Culture and Tourism also participates in the promotion of Turkish culture abroad (Kaya and Tecmen, 2011, p. 18), not only to foreigners but also to Turkish communities abroad. In accordance with a multi-dimensional foreign policy, the government has implemented a multi-dimensional strategy to promote Turkey abroad, covering a broad spectrum ranging from economy and trade to culture, from social development to education and cultural diversity. In order to promote Turkey internationally, exhibitions, 'Turkey Week' and 'Year of Turkey' events and festivals are organized; Turkey also participates in each country's existing festivals and cultural events, while conferences on Turkish foreign policy are organized and promotional publications and documentaries are produced. For instance, in 2003, 2008, 2009 and 
2013, a 'Year of Turkey' was proclaimed in Japan, Russia, France and China respectively. In 2009, which was proclaimed as 'Turkish Season' in France, 600 cultural, social, political, economic and scientific activities were organized, constituting the most comprehensive and longest series of events and promotion campaign realized abroad by Turkey in an EU country. Turkish Cultural Centres, established by the Ministry of Foreign Affairs, have the goal of promoting 'Turkish culture, language and art and to contribute to bilateral relations between Turkey and other countries, as well as to help Turkish citizens in their adaptation to the country in which they live. In addition, Turkish Language and Literature Departments and Turkish courses have been established in foreign universities, supported by lecturers and technical equipment provided by Turkey (Ministry of Foreign Affairs, 2012).

As well as these initiatives, the Yunus Emre Institute was established in 2007 to promote Turkish culture, society and language abroad. It aims to conduct research to improve the promotion and teaching of Turkish culture, history, language and literature, and to support scientific studies by cooperating with various foreign organizations and informing the wider public by publicizing the results of such activities. It also contributes to the training of academics and researchers concerned with Turkish language, history, culture, art and music and provides training through certification programmes. The institute helps to establish Yunus Emre Turkish Cultural Centres to promote Turkish language, culture, arts and history in several countries. These centres promote Turkey through cultural activities, scientific projects and courses, while aiming to increase cultural exchanges with other countries (Yunus Emre Institute, 2013). The locations of the centres reflect an emphasis on the Middle East and the Balkans which fits with the common cultural heritage approach of Turkish foreign policy (Kaya and Tecmen, 2011, p. 11). Chairs for Turkish studies have also been established in prominent universities abroad to increase the number of studies on Turkey in international universities and to establish a discussion platform about Turkey in the public opinion of foreign countries. One example is the establishment of the 'Chair of Contemporary Turkish Studies' at the London School of Economics (LSE) (Ministry of Foreign Affairs, 2012).

Thus, Turkey successfully introduced several new institutions and instruments in the first decade of the $21^{\text {st }}$ century that contributed to Turkey's soft power, such as the Office of Public Diplomacy and Yunus Emre Centres, especially in neighbouring regions. However, Turkey's 
soft power faces several recently emerging internal and external challenges. Externally, these challenges became more obvious after the Arab uprisings, particularly after the Syrian crisis while there was stagnation in the negotiations between Turkey and the EU, domestically the challenges include the problems in the field of freedom of speech and freedom of media and the rise of terrorism.

\section{External Factors Challenging Turkey's Soft Power}

Several internal and external developments strengthened Turkey's soft power during the first decade of the $21^{\text {st }}$ century. The main internal development that changed Turkish foreign policy was that the JDP Party, which has an Islamist origin, came to power in 2002, bringing with it a new political and bureaucratic elite and political agenda (Bilgin, 2008). In its first term of office, the government made Turkey's EU accession process the main priority of Turkish foreign policy, starting formal accession negotiations with the EU on 3 October 2005. Many reforms were introduced, including in the fields of minority rights, abolition of death penalty, human rights and the Kurdish issue, especially between 2000 and 2005 (which includes the pre-JDP coalition government's term in office).

During the JDP Party's second term (2007-2011), the government emphasized cultural proximity with neighbouring countries. Meanwhile, Turkey's democracy and growing economy provided a political and discursive basis for a new multi-dimensional and proactive foreign policy in addition to the country's geostrategic importance (Keyman, 2009, p. 5). The logic of JDP Party's foreign policy approach was to play a leadership role in the Muslim world while it was trying to participate in initiatives with the West, such as the Dialogue of Civilisations (Öniş and Yllmaz, 2009).

At the same time, the government attempted to construct Turkey as a 'centre' country. Thus, Turkey became more active in international organizations like the G-20, the Organization of Islamic Cooperation (OIC), and it became a temporary member of the UN Security Council for 2009-2010 period. Due to its growing economy and proactive foreign policy in various parts of the world, Turkey sometimes became referred to as a 'model country' or an 'inspiration' for other countries in the Islamic world (Keyman, 2009, p.12). Kirişçi (2011, p.35-45) argues that Turkey's 'demonstrative effect' is based on three developments: firstly, Turkey's rise as a 'trading state', which makes it more visible through trade 
and investment; secondly, the diffusion of Turkey's democratization experience; and thirdly, Turkey's new foreign policy paradigm which includes policies encouraging regional integration through free movement of goods and people between Turkey and the Middle East. For example, visa requirements for Moroccan and Tunisian nationals were lifted in 2007, and for Syrian, Lebanese and Jordanian nationals in 2009. Turkey also mediated conflicts between several regional actors, and between them and the West. Inspired by the EU as an international actor, for which the term soft power is frequently used, Turkey has in turn become an inspiration for other countries, especially in the Middle East (Kahraman, 2011, p. 711). Turkey's regional and global engagements have even expanded to Africa, Asia and Latin America. However, this increasing proactivity in regions like the Middle East and the Balkans has also been criticized as reflecting a 'neo-Ottomanism' (Ulusoy, 2005, p. 245), although Kalın (2011, p. 10), the former head of the Office of Public Diplomacy, rejects such claims about Turkey's recent foreign policy; he considers these tendencies as representing a reconciliation between Turkey and its history and geography.

More recently, Turkey's self-confidence has increased by its ability to maintain economic growth during the financial crisis in the Eurozone and its proactive foreign policy. In the third term of the JDP government (2011-2015), Turkey acted more as an independent regional power in the Middle East while emphasising mutual economic interests and a common Muslim identity (Öniş, 2014, p. 5). However, Turkey’s rising soft power faced challenges, especially after the Arab uprisings in that the new foreign policy paradigm, based on 'zero problems with neighbours', has had to deal with the realities of international politics (Kirişçi, 2011, p. 46), especially with respect to Syria. Whereas, at the beginning of the Arab Spring, there were discussions as to whether Turkey can be a 'model' or an 'inspiration' for those countries', after a while, these discussions were replaced by critiques of Turkey's over-engagement in the domestic politics of several Arab states, as it became more deeply involved in their internal sectarian conflicts.

4) TESEV's public opinion surveys in the Arab world show that Turkey has been quite attractive in the region. This attractiveness comes from a proactive Turkish foreign policy, the perception of Turkey's successful socio-economic transformation in the last decade and an increase of Turkish cultural products, particularly Turkish TV series in the region. The popularity of these series has been influential in raising the number of visitors to Turkey from Arab countries (Benli Altunışık, 2011, p. 1). 
Turkey's increasingly friendly relations with Syria between 1999 and 2008, which led to the lifting of visa requirements, was one of the main examples of how Turkey's soft power was rising in the region. However, a civil war then started in Syria with the anti-government uprisings in 2011. The authoritarian political leader Basher el-Assad has been able to hold on to power, in spite of strong resistance from various societal forces (Lesch, 2013; cited in Öniş, 2014, p. 2). Currently, Turkey's relations with Syria are as securitised as they were in the 1990s, and Turkey's foreign policy towards Syria has been transformed from soft to hard power (Demiryol, 2014, p. 10). Nevertheless, at the same time, Turkey has played an important role in providing humanitarian aid and welcoming a large number of Syrian refugees. However, the JDP's proactive foreign policy has not succeeded in facilitating regime change in Syria, nor has it helped establish and maintain a democratic order in Egypt; on the contrary, it has moved more towards entangling Turkey in the region's sectarian conflicts and deeply engaging it in the domestic politics of certain Arab states (Öniş, 2014, p. 1).

In the case of Egypt, its first democratic experiment with an elected government ended with a military coup that removed the democratically-elected President Morsi and the Muslim Brotherhood from power. In Libya, the post-Qaddafi situation is very uncertain, with extreme polarization in Libyan society. Only in Tunisia have several positive steps been taken towards political liberalisation (Öniş, 2014, p. 2). Given this context, one of the main challenges for Turkey's soft power has become how to balance its relations with authoritarian and reformist regimes. This is also related to the question of which political forces will gain power during the transition process in these countries. This new context requires differential treatment of Turkey's neighbours and consideration of their local characteristics. In addition, it is now necessary to balance 'Turkey's historical/cultural and idealist vision with more pragmatism and realpolitik' (Kahraman, 2011, p. 706).

As a result of its involvement in the Arab Spring, Turkey is no longer seen as a neutral actor in the region (Akdeniz, 2013, p. 5). As Öniş (2014, p. 2) argues, Turkey has been an increasingly assertive regional power' in recent years, who is usually perceived as a country that takes sides in the internal problems of Middle Eastern countries. Yet, despite its foreign policy activism, Turkey's ability to influence the political transformations in the Middle East has been very limited. The overactivism of Turkish foreign policy, especially in Egypt and Syria, has 
led to several criticisms both by some domestic actors, particularly the opposition parties, and within the international community. Turkey's recent interventionist and sectarian foreign policy understanding has contradicted the traditionally peaceful and non-interventionist nature of its foreign policy and its role as a mediator (Elman, 2013, p. 3).

According to the Turkish think tank TESEV's reports on the 'Perception of Turkey in the Middle East' in 2011 and 2012 (2013, p. 6), it was the most favourably-thought-of country. However, in 2013 the United Arab Emirates was the favourite (67\%), followed by Saudi Arabia (60\%) and then Turkey (59\%). However, in 2013, Turkey is still perceived as a regional model with $51 \%$, although Syrians had the least positive perception of Turkey as a model with $22 \%$. Respondents viewing Turkey as a regional model emphasize its economy and democratic regime.

Thus, there are several internal and external factors that have influenced Turkey's soft power in the $21^{\text {st }}$ century. The main external development is the Arab uprisings because it has made Turkey's neighbourhood more insecure, which in turn has made it harder for Turkey to act as a soft power. Another external crucial challenge is the stagnation in Turkey-EU negotiations, which has influenced the decline in the momentum of the reform process in Turkey. This has reduced Turkey's attractiveness as an 'inspiration' to other Middle East countries.

\section{The Role of the EU in Turkey's Soft Power}

After the Helsinki Summit in December 1999, when Turkey was given official candidate status, the Europeanization of Turkey, which was the priority of the JDP government's foreign policy during its first term of government (2002-2007), positively influenced Turkey's soft power, especially through the introduction of several reforms in the areas of democracy, human rights and minority rights. These reforms decreased the military's political influence and strengthened Turkish civil society. Öniş (2009, p. 8-9) argues that these reforms lead to a closer involvement of new actors in Turkish foreign policy, such as business organisations and CSOs. The EU also played its part in these reforms by providing funds for Turkish civil society projects and opportunities for new interactions between civil society in Turkey and EU member states, thereby increasing the number of Turkish CSOs and professionalisation of Turkish civil society.

However, following their launch in October 2005, the EU accession negotiations rapidly stalled because of the Cyprus issue and the resolute 
opposition to Turkey's full membership by the French and German governments, who are the major motors of European integration. Till now, sixteen chapters have been opened but only one could be provisionally closed. In addition, the level of support of Turkish public opinion for the EU process has decreased in parallel with these developments. ${ }^{5}$

Especially during the second term (2007-2011) of the JDP government, Turkey developed a proactive multidimensional foreign policy. Although declining in recent years particularly after the economic crisis, only Turkey's relations with the EU exert transformative power over Turkey. Therefore, these relations are crucial if Turkey wants to act as a key actor for promoting democracy in its neighbouring regions (Öniş, 2014, p. 15). The Arab world started to take a closer interest in Turkey, especially after membership negotiations started with the EU, and several public opinion surveys show that Turkey's contributions to the region's stability, economic and political development are closely linked to Turkey's relations with the EU (Kirişçi, 2011, p. 34-49) and progress in the reform process in Turkey.

The Customs Union between Turkey and the EU since 1996, and the prospect of EU accession raised the competitiveness of Turkish industry and improved Turkey's position as a destination for Foreign Direct Investment (FDI). Meanwhile, there has been an increase in Turkish trade with its non-EU neighbours, which has led to a reduction in the EU's share of Turkish exports from 56\% in 2002 to $38 \%$ in 2012. However, the future of the Turkish and EU economies will remain intertwined (The Independent Commission on Turkey, 2014, p. 27-31). In spite of a decline in recent years, Turkey's primary trading partner is still the EU, accounting about $40 \%$ of its total trade in 2012 . The EU is also the largest foreign investor in Turkey, accounting for three-quarters of FDI inflows to Turkey (Akdeniz, 2013, p. 1).

The Arab Spring created a much more difficult foreign policy environmentforboth Turkeyand theEU in theircommon neighbourhood. Developments in Turkey's neighbourhood have brought to the forefront its relations with Europe in political and security terms; the EU has become the priority for Turkey again also economically with the setbacks in economic relations with its neighbours. Thus, the acceleration of the momentum of domestic reforms and economic growth can regenerate Turkey's soft power potential (Akdeniz, 2013, p. 5).

5) For further detail, see Eurobarometer surveys. 
The latest report of the Independent Commission on Turkey (2014) stated that, although the Turkish government has remained in principle committed to the EU accession process, it has seemed to attach less importance to the EU process since 2007.

While there has been an ongoing transformation processes in the Middle East, Turkey has been seen as an 'inspiration' because of having a secular democracy while having a predominantly Muslim population. One of the main sources of the legitimacy of Turkey's role as an 'inspiration' has been its domestic transformation in accordance with $\mathrm{EU}$ values and norms during the EU integration process (Oğuzlu, 2013, p. 11). That is, as AydınDüzgit and Keyman (2014) argue, it is mostly Turkey's EU membership prospect that makes it an attractive example of regional democracy.

The EU and Turkey have established a regular foreign policy dialogue which has intensified in recent years. The EU's former High Representative for Foreign Affairs and Security Policy, Catherine Ashton and Turkish former Prime Minister Ahmet Davutoğlu had regular constructive talks since 2010, on issues including the Western Balkans, Middle East and North Africa, Russia and Central Asia (The Report of the Independent Commission on Turkey, 2014, p. 43-44). In spite of the intensification of this political dialogue between the EU and Turkey concerning international issues of common interest, Turkey's alignment with relevant EU declarations and Council decisions has remained at only around 50\% in recent years. There are many divergent Turkish and EU positions on key issues, such as military intervention in Egypt. On the other hand, the 'Positive Agenda' was initiated by the Commission to complement the negotiation process. In December 2012, the Commission prepared a road map for visa liberalisation with Turkey, which includes the requirements that need to be fulfilled by Turkey, including implementation of the readmission agreement. Turkey signed the readmission agreement in December 2013 and the visa liberalisation process will take place in three years' time, if the necessary steps for implementing readmission agreement will have been taken by Turkey (Akdeniz, 2013, p. 2).

Especially since the crisis in the Eurozone and stagnation in the negotiation process, the desirability of becoming an EU member has gradually decreased in Turkey, which has weakened the EU's role as an anchor of democratic reform in Turkey (Cenker Özek and Oğuzlu, 2013, p. 697). Yet, in spite of these challenges, the EU still provides the best anchor for Turkey to consolidate its democracy and improve freedoms, develop economically and increase its regional influence (Akdeniz, 
2013, p. 10). Indeed, several scholars, including Keyman, Aydın and Açıkmeşe, consider that this anchor is still crucial. ${ }^{6}$ However, Turkey also needs some positive signals from the EU because the enthusiasm of Turkish public opinion for the EU has decreased significantly in recent years. Lifting of Schengen visas for Turkish citizens could be an important positive signal. In addition, opening new chapters, especially chapter 23 on Judiciary and Fundamental Rights and Chapter 24 on Justice Freedom and Security, may help revitalize the reform process in Turkey in these policy fields, where there are still crucial deficiencies.

\section{Domestic Challenges Facing Turkey's Soft Power}

The 'image' of a country is crucial for its soft power. To improve its image, Turkey has to maintain its economic growth and develop towards a pluralist democracy. As Oğuzlu (2013, p. 12) puts it, 'soft power begins at home', adding that 'legitimacy and attractiveness abroad comes with legitimacy and attractiveness at home. The JDP government emphasizes Turkey's internal transformation as the most important source of Turkey's soft power abroad. Turkey's ability to influence regional developments and to become an 'inspiration' for the other countries depends on its ability to continue the reform process and evolve into a pluralist democracy. Thus, Turkey's internal characteristics and its domestic transformation process play a crucial role in its soft power. Turkey's attractiveness as a source of 'inspiration' for transitional regimes in the Middle East will be influenced by whether Turkey maintains its high economic growth rates while continuing to democratize. As Oğuzlu (2013, p. 15) argues, 'plural democracy, rather than majoritarian democracy needs to take root at home'.

Moreover, inconsistencies in the government's policies and rhetoric in foreign policy and domestic politics have reduced its reliability. For example, the JDP government harshly criticized the military coup in Egypt, and was critical of EU leaders for not being equally critical and responsive. However, this high level of sensitivity and prodemocratization rhetoric towards events in other countries are not credible and consistent because of crucial deficiencies in Turkey's own democratic credentials and pluralist political order (Öniş, 2014, p. 15).

6) For further detail, see Fuat Keyman, "Globalization, Modernity and Democracy"; Mustafa Aydın and Sinem A. Açıkmeşe, "Europeanization through EU Conditionality: Understanding the New Era in Turkish Foreign Policy", Journal of Southern Europe and the Balkans, Vol. 9, No. 3, 2007, p. 263-274. 
On the other hand, in recent years, freedom of expression and freedom of the press has narrowed in Turkey. In February 2014, for example, the Turkish Parliament passed a new Internet law which allows the telecommunications authority to block any website within 24 hours and requires all internet providers to store data on users' activities and make it available to authorities on request. While, in 2005, Turkey ranked $98^{\text {th }}$ out of 178 countries in the Reporters Without Borders' Annual Index of Press Freedom, it dropped to $154^{\text {th }}$ in 2013 (The Report of the Independent Commission on Turkey, 2014, p. 15). Because of all these internal problems, EU membership prospect still has a crucial role for democratization of Turkey.

The deepening polarisation in Turkey between political actors and within society also hinders the consolidation of its democracy (The Report of the Independent Commission, 2014, p. 46). Moreover, the rise of PKK terrorist attacks and DAESH terrorism in Turkey, have increased the role of security and have challenged the balance between freedom and democracy especially since July 2015. Thus, in spite of its deficiencies, the EU accession process is still crucial for Turkey for sustaining its transformation and democratisation.

\section{Concluding Remarks}

Turkey, which has a democratic and secular political system with a predominantly Muslim population and, since 1999, the prospect of EU membership, has had an increasing influence in its neighbouring regions especially during the first decade of the $21^{\text {st }}$ century. The first and second JDP governments tried to contribute to regional peace through constructive engagement and mediation efforts. Turkey's 'zero problems policy' approach contributed to Turkey's soft power, which includes a liberal visa policy with its neighbours and increasing communication and cooperation in the fields of economics, politics and culture.

However, the strategy of externally promoting and projecting Turkish culture, which lies at the core of the country's soft power, is insufficient as long as hard power and uncertainty dominate in the Middle East (Benli Altunışık, 2011, p. 2-3). As Oğuzlu (2007, p. 95) argues, when threats and challenges to Turkey's own security go on, it will probably lead to an increase in its tendencies to act as a 'hard power'. Similarly, growing tensions between Turkey and Syria, the rise of terrorism, stalled negotiations with the EU, and the loss of momentum 
of the reform process, particularly regarding freedoms of speech and the media, have reduced Turkey's soft power in recent years.

As Kaya (2013, p. 57-59) argues, there is a difference between the ways in which the JDP government and the pro-European groups perceive the sources of Turkey's becoming a regional soft power. The JDP emphasizes cultural and historical ties in its neighbouring regions, while pro-European groups in Turkey mostly believe that 'Turkey's growing regional influence derives from its European perspective'. As Öniş (2014, p. 14-15) argues, Turkey can have crucial influence in its region by becoming a reference point through its level of economic development and by improving its democratic credentials. Thus, Turkey's ability to act as a 'role model' for the region will depend mostly on maintaining and improving its economic situation and overcoming its democratic deficits by consolidating its democracy. Especially during the third-term of the JDP government, Turkey has implemented a more interventionist proactive foreign policy in the region with increasing self-confidence. However, Turkey's foreign policy in the Middle East after the Arab uprisings, especially towards Egypt and Syria, show the limits on the constructive impact of unilateral activism' (Öniş, 2014, p. 15), which indicates the importance of 'cooperative action through multilateral channels'.

The recent failed coup attempt which on 15 July 2016, shows that in spite of the polarisation in the society different parts of the society and all of the political parties represented at Turkish Parliament stood against the coup attempt. The developments after the coup attempt will be very crucial for Turkish democracy and Turkey's position as a regional power. In order to be an influential regional power which promotes peace and stability in its region Turkey needs to overcome polarisation within the society and go on the reform process particularly in the fields of freedom of speech, freedom of media and rule of law.

Consequently, there are several internal and external challenges influencing Turkey's regional power in the second decade of the $21^{\text {st }}$ century. The biggest external challenges include the Syrian crisis and the growing influence of extremist Islamist groups, such as DAESH (The Report of the Independent Commission on Turkey, 2014, p. 42). One of the main domestic factors which influence Turkey's soft power is the Kurdish issue, which is also influenced by external regional developments. Secondly the integration of Syrian asylum seekers in Turkey is crucial. Thirdly the attitude of the government regarding freedom of speech, freedom of the media and individual liberties will 
also influence Turkey's soft power. If Turkey can re-start its reform process in these fields then this will help Turkey move towards a more pluralist democracy. These developments would also bring a new dynamic to the stalled negotiations with the EU. Improvements in these domestic fields will improve Turkey's soft power. Thus, the EU anchor is still crucial in Turkey's transformation process for overcoming all these domestic challenges which will make Turkey more a country of 'inspiration' in its region. As Nye (2009, p. 162-163) argues, in today's world, success is not only based on 'whose army wins but also of whose story wins'. To create its own successful story, which is crucial for soft power, Turkey has to overcome its deficiencies in its democracy, improve its economic position, increase its economic growth rates and develop a more constructive, balanced, multilateral and consistent understanding of Turkish foreign policy.

\section{References}

Akdeniz, A. (2013), EU-Turkey relations, towards a constructive reengagement?, TESEV Publications.

Aydın-Düzgit, S. and E. F. Keyman (25 March 2014), Democracy support in Turkey's foreign policy, Carnegie Endowment for International Peace, Available at: http://carnegieendowment.org/2014/03/25/democracysupport-in-turkey-s-foreignpolicy/h5ne

Beng, P. K. (2008), Turkey's potential as a soft power: A call for conceptual clarity', Insight Turkey, Vol. 10, No. 2.

Benli Altunışı, M. (June 2011), Challenges to Turkey's soft power in the Middle East, Istanbul: TESEV Pub.

Bilgin, H. D. (2008), Foreign policy orientation of Turkey's pro-Islamist parties: A comparative study of the AKP and Refah, Turkish Studies, Vol. 9, No. 3.

Cerem I., C. Özek, and T. Oğuzlu (2013), Beyond the institutional logics: International level systemic analysis of EU-Turkish relations', Turkish Studies, Vol. 14, No. 4.

Demiryol, T. (2014), Poverty of soft power: Evidence from Turkish foreign policy in the Middle East, European Journal of Research on Education, Special Issue: International Relations.

Elman, P. (July 2013), 'Turkey at a tipping point: Why the EU should use Gezi to rebalance Ankara's foreign policy, The Polish Institute of International Affairs Policy Paper, No. 17 (65). 
Faaliyetler (Activities) (2010), Başbakanlık KamuDiplomasisi Koordinatörlüğü (Turkish Prime Ministry Public Diplomacy Office), Available at: http:// kdk.gov.tr/faaliyetler/15 (Accessed 16 February 2013).

Kahraman, S. (December 2011), Turkey and the EU in the Middle East: Reconciling or competing with each other?, Turkish Studies, Vol. 12, No. 4.

Kalın, İ. (Autumn 2011), Soft power and public diplomacy in Turkey, Perceptions, Vol. 16, No. 3.

Kamu Diplomasisine Bakış (2010) (Looking Towards Public Diplomacy), Başbakanlık Kamu Diplomasisi Koordinatörlüğü (Turkish Prime Ministry Public Diplomacy Office), Available at: http://kdk.gov.tr/sag/kamudiplomasisine-bakis/21 (Accessed 28 January 2013).

Kaya, A. (July 2013), Yunus Emre cultural centres: The AKP's neo-Ottomanism and Islamism, Perspectives, Heinrich Böll Stiftung Turkey Representation, Istanbul.

Kaya, A. and A. Tecmen (2011), The role of common cultural heritage in external promotion of modern Turkey: Yunus Emre Cultural Centres, Working Paper, No. 4.

Keyman, E. F. (December 2009), Turkish foreign policy in the era of global turmoil, SETA Policy Brief, No. 39,

Kiriş̧̧i, K. (2011), Turkey's 'demonstrative effect' and the transformation of the Middle East, Insight Turkey, Vol. 13, No. 2.

Ministry of Foreign Affairs of Turkey. Available at: www.mfa.gov.tr (Accessed 18 November 2012).

Nye, J. (Autumn 1990), Soft power, Foreign Policy, No. 80.

Nye, J. (2004), Soft Power: The Means to Success in World Politics, New York: Public Affairs.

Nye, J., (2008) Public diplomacy and soft power, The ANNALS of the American Academy of Political and Social Science, Vol. 616, No. 94.

Nye, J. (July-August 2009), Get smart: Combining hard and soft power, Foreign Affairs.

Oguzlu, T. (2007), Soft power in Turkish foreign policy, Australian Journal of International Affairs, Vol. 61, No. 1.

Oğuzlu, T. (July 2013), The Gezi Park protests and its impact on Turkey's soft power abroad, Ortadoğu Analiz, Vol. 5, No. 55.

Öniş, Z. (2014), Turkey and the Arab revolutions: Boundaries of regional power influence in a turbulent Middle East, Mediterranean Politics, Vol. 19, No. 2, DOI: 10.1080/13629395.2013.868392. 
Öniş, Z. and Ş. Yllmaz (Spring 2009), Between Europeanization and EuroAsianism: Foreign policy activism during the AKP era, Turkish Studies, Vol. 10, No. 1.

TESEV Report (January 2014), TESEV Foreign Policy Programme, M. Akgün and S. Senyücel Gündoğar, The perception of Turkey in the Middle East 2013, İstanbul.

The Independent Commission on Turkey, $3^{\text {rd }}$ Report (March 2014), 'Turkey in Europe: The Imperative for Change'.

TİKA (Türk İşbirliği ve Koordinasyon Ajansı Başkanlığı). Available at: http:// www.tika.gov.tr/tika-hakkinda/1 (Accessed 12 February 2013).

Ulusoy, H. (October 2005), A Constructivist Analysis of Turkey's Foreign and Security Policy in the Post-Cold War Era. PhD Thesis, Middle East Technical University.

Vizyon ve Misyon (Vision and Mission) (2010), Başbakanlık Kamu Diplomasisi Koordinatörlüğü (Turkish Prime Ministry Public Diplomacy Office), Available at: http://kdk.gov.tr/kurumsal/vizyon-misyon/8, (Accessed 12 February 2013).

Yunus Emre Institute. Available at: http://yunusemreenstitusu.org/turkiye/ index.php?lang=en\&page $=68 \&$ anIIcat_1=0\&anIIitm_1 $=1$ (Accessed 15 February 2013). 